\title{
A Case for the Modifiability of the San Francisco Peace Treaty: Examining the Varying Positions of the U.S. and Britain Over South Korean Participation
}

\author{
Yi Tae-Jin \\ Seoul National University, Seoul, Republ ic of Korea
}

\begin{abstract}
Through a detailed analysis and documentation of relevant U.S. foreign relations and other official documents of the period around the Korean War, this paper aims to prove that in the early negotiation process of the 1951 San Francisco peace treaty, the United States maintained that South Korea should participate in signing the treaty and that the U.S. changed its position because of the resilient British opposition to South Korean participation, which in turn was motivated strongly by the British concern over its strategic interests in East Asia and its diplomatic relations with the newly communized China. In particular, the Chinese intervention in the Korean War and the communist recapture of Seoul provided the impetus for this shift in the U.S. position that led to the exclusion of South Korea from the treaty. Because the substance of the San Francisco peace treaty was dictated by the exigencies under the Korean War and the Cold War and lacks the "Grotian spirit of international law" underlying the founding of the League of Nations and the United Nations, the San Francisco peace treaty does not contain sufficient merit to be worthy of permanent compliance, which leaves open the possibility of modification in the future.
\end{abstract}

Keywords: the San Francisco Peace Treaty, the US-Japan security treaty, British objection to South Korean participation, Communist China, the Korean War, the Cold War, the 1905 Protectorate Treaty, Grotian spirit of international law

\section{Introduction}

Since the early 1990s, the present writer has examined the illegality of the treaties the Japanese Empire forced upon the Korean Empire in order to deprive it of its national sovereignty. What has been scrutinized is the progression in which the Japanese Empire, after launching the Russo-Japanese War in early February 1904, deployed massive troops in Korea, a non-belligerent country, and forced a series of treaties relating to the use of military installations, foreign relations power, and domestic governance, which eventually led to the "annexation" of Korea in August 1910. What has been proven is the facts that most of the defects and disqualifying qualities of each treaty document were the results of coercion based on military might, that all treaties lacked ratification statements issued by the head of state (the Korean Emperor), and that the signature of the Korean Emperor used in approving imperial orders, imperial edicts, and statutes was forged. The coercive and unlawful nature of the five major treaties, executed in the six-year period under the threat of military force, has been clearly demonstrated.

Yi Tae-Jin, Emeritus Professor, Department of Korean History, College of Humanities, Seoul National University, Seoul, Republic of Korea. 
After the coerced annexation on August 29, 1910, Koreans carried out various anti-Japanese campaigns in and outside the Korean peninsula, and U.S. President Wilson's proclamation of the doctrine of national self-determination prompted a nationwide demonstration for independence on March 1, 1919, which marked a turning point in the movement for the restoration of national sovereignty. Even as the cry for independence continued within the peninsula, anti-Japanese activists gathered on April 11 in the Shanghai French Concession, set up the National Assembly, and established the Provisional Government of the Republic of Korea (Daehan Minguk), which was named after the Great Korean Empire (Daehan Jeguk) to signify its intent to succeed the Empire.

While conducting research on the Korean Provisional Government (KPG)'s efforts to engage the leaders of the great powers with a view to restoring Korea's national sovereignty, the present writer came to recognize the historic import and relevance of The League of Nations. What caught the interest of the present writer in particular was the codification of international law that was suggested and executed by Professor Manley Otto Hudson of the Harvard Law School from 1927 to 1935, which elevated the status of international law, previously regarded as mere academic theories postulated by individual jurists, to the sphere of public law. This was intended to lay the foundation for a break with the ills of territorial expansionism that the great powers pursued through secret agreements even up until the early 20th century. The Report on the Law of Treaties, reported by Professor James Garner of the University of Illinois who was acting under the aegis of Professor Hudson, lists among those treaties that were without any legal effect: (1) the 1773 Treaty of Partition that Russia coerced on the members of the Diet of Poland; (2) the 1905 "Protectorate Treaty" that Japan coerced on the Korean emperor and high officials; and (3) the 1915 Treaty that the U.S. coerced on the Haitian national assembly by surrounding it with the U.S. Marines. The 1905 "Protectorate Treaty" was the treaty that, by depriving the Great Korean Empire of its foreign relations power, paved the way for its annexation.

In a paper submitted to the Third Conference held in Wuhan University, the present writer focused on the fact that Professor Hudson viewed the codification of international law by the League of Nations as a renewal of "the Grotian spirit of international law in the 20th century." ${ }^{1}$ Under this banner a march was initiated toward ending the history of the invasion of weak nations by the great powers and toward reestablishing international justice. The paper places emphasis on the fact that this achievement, made under the initiative of Professor Hudson, was handed over in toto to the International Law Commission of the United Nations newly launched in 1946. Having inherited the 1935 Report on the Law of Treaties from the League of Nations, this Commission conducted supplementary work and submitted a new report to the UN General Assembly in 1963, which adopted it in Resolution 1902. In this report, the Commission added the Munich Agreement (Munich Betrayal) of September 1938, which was pursued by Nazi Germany in order to partition Czechoslovakia, to the above list of the three coercive treaties that were without any legal effect. "The Grotian spirit of international law in the 20th century" was upheld and retained also in the United Nations.

Having reviewed whether the Japanese Peace Treaty signed in San Francisco on September 6, 1951 was in keeping with the spirit of international law as embodied by the League of Nations and the United Nations, the present writer submitted findings of such a review to the Wuhan University Conference. It was difficult to find

\footnotetext{
${ }^{1}$ Yi Tae-Jin, 2018, "Expectations for the New International Order of East Asia in the 21st Century-Beyond the San Francisco System”, Beyond the San Francisco System, Wuhan, China, 27-28 October. The present writer presented the following papers at the Columbia Conference in November 2016 and at the UPenn Conference in December 2017, respectively: (1) Yi Tae-Jin, “The San Francisco Peace Treaty and the Problems Regarding Japan's Exemption from Blame for the Colonization of Korea,” Cultural and Religious Studies 6, no. 1, (January 2018): 33-50; (2) Yi Tae-Jin, "The Treaty of San Francisco from the Perspective of International Peace Movement in Early Twentieth-Century,” Cultural and Religious Studies 6, no. 2, (January 2018): 88-111.
} 
the spirit of the League of Nations and the United Nations in the Peace Treaty with Japan. The preamble to the treaty nor the text of the treaty had little, if any, reference or allusion to the spirit behind the establishment of the United Nations. If the "Report on the Law of Treaty" in 1935 and its successor, i.e., the International Law Commission Report (item 69 of its 15th session) were adopted in 1963 by the United Nations General Assembly Resolution 1902 of its 18th session, found Japan's protectorate treaty with Korea void ab initio and the consequent Japanese rule of Korea ipso facto illegal, it follows that Korea should have been allowed to participate as a signatory and ratifying state to the Japanese peace treaty in order to remedy such an illegality. Eventually, however, Korea was excluded on the grounds that it was a part of Japanese territory during 1910-1945 and that it was not a belligerent state in the war against Japan.

In the Wuhan Conference, the present writer pointed out this issue and offered a critical opinion that the substance of the treaty was dictated by the exigencies under the Cold War system and that as such, it does not contain sufficient merit to be worthy of permanent compliance. At the conclusion of the Wuhan presentation, the present writer particularly noted that in the early negotiation process, the United States insisted that South Korea must participate in signing and ratifying the treaty. The present writer also remarked that the next task would be to explain why and how the British and Japanese opposition to South Korean participation eventually led to the exclusion of South Korea from the treaty. The current presentation serves as an answer to that question.

\section{The Korean War in 1950 and the Chinese Red Army's Entry Into War: Impetus for the San Francisco Peace Treaty}

The Pacific War ended on August 15, 1945, when Emperor Hirohito of the Japanese Empire declared Japan's “unconditional surrender." On August 21, the US government proposed the establishment of The Far Eastern Advisory Commission to the Soviet, British, and Chinese governments as an organization for the control of the defeated Japan. With this proposal, the council of representatives from the four countries renamed the Commission the Far Eastern Commission (FEC), giving the U.S. government the function of policy recommendation to implement the various provisions of the Japanese Instrument of Surrender. From July 10, 1947 to December 23, 1948, the FEC did in fact determine the 13 policies on disarmament, democratization, and economic recovery.

Efforts toward devising a peace treaty to restore Japan to the community of peaceful nations made very little headway among the countries concerned until $1949 .{ }^{2}$ In September of the same year, US Secretary of State Dean Acheson and British Foreign Minister Ernest Bevin met in Washington to agree in principle on a peace conference, excluding the Soviet Union. At this point the peace conference was under preparation, but no real progress was forthcoming. On January 12, 1950, the Acheson Line of defense was declared, and on January 15, a group of Japanese intellectuals known as the Discussion Group on the Matters of Peace 平和問 題討論會issued the Statement on Peace Issues. But actual progress remained elusive. In February, the opposition Republican Party in the U.S. Congress condemned the failure of the Truman administration on its China policy. Then McCarthyism erupted, and President Truman pursued bipartisan diplomacy. In April, the

\footnotetext{
2 From November 1945 to May 1947, “The Board of Governors for the Research of the Peace Treaty Issues” 平和條約問題研究 幹事會 was established within the Japanese government, and preparations for drafting the treaty were made by "the Working Group on Japan Treaty” in the U.S. State Department from 1947-1948. See Jeong Byung-jun 鄭秉峻, Dokdo 1947 독도 1947 [Liancourt Rocks 1947], (Seoul: Dolbege, 2010), chapters 3 and 4.
} 
president named Republican George Foster Dulles as a consultant to the Secretary of State and in May, the president officially appointed him special representative of the President to negotiate the Japanese peace treaty. ${ }^{3}$ After visiting Tokyo, Dulles traveled to Seoul for three days from June 18 to carry out his mission, and on June 25, the North Korean People’s Army crossed the 38th parallel into South Korea and initiated a war. Thus, the beginning of negotiations for the Japanese Peace Treaty coincided with the breakout of the Korean War. Thereafter, it took months for Dulles to devise and present his own strategy. After the Chinese intervention in the Korean War in late October, he insisted on the urgency of signing the peace treaty with Japan.

John Moore Allison, a senior officer for Far Eastern Affairs in the US State Department, sent a memorandum of December 2, 1950 titled "Japanese Peace Treaty" to the Consultant to the Secretary of State, John Foster Dulles. ${ }^{4}$

The memorandum states as follows:

“1. I have been thinking over our conversation yesterday with particular reference to that portion in which you [Dulles] suggest we should make an immediate study of Far Eastern Commission decisions and the surrender instrument with Japan with a view to ascertaining how far we can go without a Treaty toward giving Japan freedom of action in local and international affairs, I believe the time has come and the situation is so serious that more drastic measures are necessary.

2. In my opinion, attempts by the United States to give Japan a larger degree of freedom than she now possesses within the limits of existing FEC policy decisions would not only be extremely difficult, but would expose us to a charge of insincerity by our allies and would not, in fact, get the results desired.

3. Exhaustive studies have been made as to what can be done within the framework of present FEC directives and they have shown it is comparatively little. Also, General MacArthur has vigorously opposed this conception. I do not believe the Japanese would be satisfied with what we could do in this limited way.

4. Therefore, serious consideration should now be given to going to our friends on the FEC and pointing out frankly and forcefully that the present situation is so serious and present conditions so utterly different from those contemplated at the time the Far Eastern Commission was set up, that we are no longer in a position to abide by the terms of reference of the Far Eastern Commission or its previous decisions. This would be an honest straightforward position to take, and I believe would be understood by our friends. We would naturally want to assure them that we have no intention of allowing Japan to become a threat in any way to this interest, and that we would take steps to see that such a situation did not develop.”

Having noted that after the end of the Pacific War, the U.S. followed the FEC decisions concerning Japan, Allison went on to argue that a new strategy should be adopted to take into consideration the drastic changes that occurred-presumably upon the outbreak of the Korean War. The memorandum then continues with the following recommendation:

5. I believe we would then be in a position to recommend to them that they acquiesce in our desire to bring Japan into our family of nations as a free and independent member, with which we could make agreements for military assistance on a basis of equality in an attempt to get Japan on our side voluntarily and not by force. In my opinion, we should endeavor to get the Japanese to agree, with respect to their own defense and the defense of the Japan area, to furnish ground forces (the U.S. furnishing ground forces only until Japanese forces could take over) while the United States and such other of our allies as agreed with us and would come in on our terms, would furnish air and naval forces. The fact that Japan would not

\footnotetext{
${ }^{3}$ See Fukunaga Fumio 福永文夫, “Sanfuranshisuko kōwa - senryō no shūketsu” サンフランシスコ講和—占領の終結 [San Francisco Peace Conference-The End of Occupation], in Nihon senryos̄hi, 1945-1952: Tokyo-, Washington, Okinawa 日本占領 史-1945-1952, 東京・ワシトン·沖繩 [A History of the Occupation of Japan, 1945-1952: Tokyo, Washington, Okinawa] (Tōkyo, Chūko, Shinsho, 2014).

4 J. M. Allison to John Forster Dulles, December 2, 1950, microfilm, USE Micro-copy No. Coo 43 (UPA) Roll No.(s) 1, Declassified NND 867209 RG 59 Entry Japanese peace treaty 1947-52 Box 1, (copies to Mr. Rusk, Colonel Babcok, NA-Mr. Johnson), pp. 55-66.
} 
have air and naval forces would go far, it seems to me, toward reassuring our allies that Japan would not be in a position to threaten their interests, and that the arrangement would be one primarily for defense of Japan and the Japanese area. This agreement should be couched in U.N. Charter terms in so far as possible and considerations might well be given to having Japan become a co-signatory of any possible mutual defense arrangements which might be entered into with New Zealand, Australia, and the Philippines.

Attached to this memorandum was a draft of an agreement between the United States and Japan. To be precise, it was titled the "Agreement between the United States and Japan for Collective Self-defense made pursuant to the Treaty of Peace between Japan and the Allied Powers and the provisions of Article 51 of the Charter of the United Nations.” The draft agreement consists of a preamble with five points and a text comprising four clauses. Also included was the "Jurisdictional Status of United States Forces Abroad." It is logical to assume that this was a preliminary draft of "The Security Treaty Between the United States and Japan” signed between the United States and Japan on the same day as the San Francisco Peace Treaty, which in turn formed the basis for the security treaty.

The North Korean People's Army, which had crossed the 38th parallel southward on June 25, 1950, began to retreat to the north on September 15, following the success of the UN forces' amphibious landing behind North Korean lines at Inchon, executed under the command of General MacArthur. On September 28, the UN forces restored Seoul, crossed the 38th parallel northward, and captured Pyongyang on October 19, and a band of the Korean army arrived at the Yalu River. On October 19, however, the Chinese troops intervened and penetrated into Korean soil through a mountain route between Ganggye and Hamheung in Hamgyeong Province. Allison's memorandum was issued on December 2, 1950, when the UN forces were being driven back south by the Chinese Red Army. As the memorandum states, the situation of the Far East at the time could no longer be bound by the FEC's policies and decisions, which was based on a sanction regime against the defeated Japan. Under the circumstances where the four main members of the Committee (U.S., Britain, Soviet Union, and China) split in half and waged war against each other, the FEC policies could not be maintained any further. US State Department Far Eastern Affairs officer Allison's proposal focused on military preparedness to protect Japan's mainland. The Chinese intervention in the Korean War made the possibility of a Soviet invasion of Japanese territory through Sakhalin appear more realistic, giving urgency to timely preparation against such a possibility. This was why the San Francisco Peace Treaty was accompanied by the U.S.-Japan Security Treaty. The US government was deeply concerned that China and the Soviet Union might attack both Japan and South Korea in an all-out war against the free world.

On January 4, 1951, the ROK forces failed to repel the southward thrust of the Chinese Red Army and decided to withdraw from Seoul. The same day (January 4), consultant John Foster Dulles sent a letter to Secretary of State Dean Gooderham Acheson about the situation of the Far East. ${ }^{5}$ Having said that he had a discussion the day before with Rusk, Allison, and the Joint Chiefs of Staff regarding how to proceed to a Japanese peace settlement, Dulles presented his opinions in detail as follows:

First, although the joint memorandum of the Secretary of State and the Secretary of Defense, dated September 7, 1950, which was approved by the President and issued as the Presidential directive of September 7th, stipulated that there should be no definitive Japanese peace settlement "until after favorable resolution of the present

\footnotetext{
5 John Foster Dulles to Dean Gooderham Acheson, January 4, 1951, microfilm, USE Microcopy No. Coo43 (UPA) Roll No. (s) 1 , Declassified NND 867209 RG 59 Entry Japanese peace treaty 1947-52 Box 1, (copies to Mr. Rusk, Colonel Babcok, NA-Mr. Johnson), pp. 13-16. The "top secret” mark on the top of this document has been crossed out.
} 
United States military situation in Korea," the Chinese Communist intervention in Korea has made it seem unlikely that there would be any such "favorable resolution.” And, in consequence, active negotiations have necessarily been in suspense for about six weeks pending modification of the Presidential directive of September 7th. This delay has worked against the long-range interests of the United States in relation to Japan in the sense that:

1. The Japanese people and their leaders are coming increasingly to feel the danger of throwing in their lot with us in view of the fact that Communist power seemed to be closing in upon them, and also upon their normal sources of food supply from French Indochina, Siam, and Burma. It would be difficult to assuage such increasing doubt on the part of the Japanese leaders as to the wisdom of any definitive commitment to our cause at the present time unless perhaps under conditions as to military and economic security which it would not be easy for us to fulfill.

2. The United Kingdom is seeking to gain the initiative and is itself drafting a Japanese peace treaty. This apparently is being now considered in London by the Commonwealth Prime Ministers, who are also reported to be considering a Pacific Pact. The British policy in relation to the Far East is different in many essential respects from ours, and the British Commonwealth proposals probably will not adequately take account of our vital interests in this area. 6 In sum, the delay in our delaying the Japanese peace settlement has not worked to our advantage.

Dulles then related two principal reasons why the Joint Chiefs of Staff desired further delay as follows:

1. To preserve our exiting authority in Japan until after the Korean affair is liquidated; and

2. To reinforce Japan with additional United States land forces lest the Soviet might move its own armed forces into Japan either as an "occupying" power under the Surrender Terms or on the theory that the Sino-Soviet Treaty of February 1950 requires this because of the remilitarization of Japan.

To this, Dulles stated that neither of these reasons was valid in his opinion: "In my opinion, further delay will substantially increase the risk that it will be impossible to obtain an unreserved Japanese commital, in fact as well as form, to our cause on conditions which we would regard as acceptable.” This letter was sent also to the secretarial office of Defense Secretary George C. Marshall.

According to the letter of Dulles, the U.S. officials were very concerned about the Soviets' possible entry into Japanese territory following Chinese intervention in the Korean War. Clearly, heightened concern about a possible Soviet invasion of Japan was a decisive factor in hastening the signing of the San Francisco Peace Treaty and the US-Japan Security Treaty in September 1951.

\section{The Differing Positions of the U.S. and the U.K. on Korean Participation}

\section{A Review of Their Changing Positions}

After the memorandum of Dulles dated January 4, 1951, the US government consulted with the British government for the early conclusion of a Japanese peace treaty and an accompanying US-Japan security treaty. The two countries disagreed over the issue of South Korea's participation in signing and ratifying the peace treaty. Table 1 below summarizes the changing opinions of the US and British governments - since the Japanese Empire's declaration of unconditional surrender on August 15, 1945-on whether a South Korean

\footnotetext{
6 The United Kingdom held Commonwealth Conferences, such as the Canberra Conference in 1947 and the Colombo Conference in January 1950. In the meantime, the British government was in contact with the US State Department, discussing stabilization in Southeast Asia and the rearmament of Japan. The Colombo Conference was marked with differing opinions among Commonwealth members, and a separate Commonwealth Working Committee was formed to delegate consultations. But especially with regard to the issue of rearmament of Japan in a proposed "Pacific pact," a series of difficulties in proceedings arose amid strong opposition from India, Australia, and New Zealand. See Kibata Yōichi 木畑洋一, “Tainichi kōwa to ikirisu no ashia sēsaku”對日講和とイキリスのアシア政策 [Japanese Peace Treaty and Britain’s Asia Policy], in Sanfuranshisuko kōwa サンフランシスコ講和[San Francisco Peace Treaty], ed. Watanabe Akio and Miyazato Sēgen (Tōkyō: Tōkyō Daigaku Shuppan-kai, 1986).
} 
representative should be invited to participate in the signing of a peace treaty between the Allied Powers and Japan. The table also includes the South Korean government's expressions of its will to participate. ${ }^{7}$

Table 1

Shifting Stances of the United States and United Kingdom Over South Korean Participation in the Japanese Peace Treaty

\begin{tabular}{|c|c|c|c|}
\hline Dates & United States & United Kingdom & Notes \\
\hline Oct. 1945 & \multirow{4}{*}{$\begin{array}{l}\text { permitted South Korean } \\
\text { participation }\end{array}$} & & $\begin{array}{l}\text { A working group for the treaty was established in the } \\
\text { US State Department. }\end{array}$ \\
\hline August 29, 1947 & & & $\begin{array}{l}\text { The interim Legislative Assembly of South Korea } \\
\text { conveyed to the US State Department its desire to } \\
\text { participate in the anticipated peace conference with Japan. }\end{array}$ \\
\hline Dec. 1949 & & & $\begin{array}{l}\text { A US draft treaty included South Korea as a signatory } \\
\text { state. }\end{array}$ \\
\hline Jan. 1950 & & $\begin{array}{l}\text { opposed South Korean } \\
\text { participation }\end{array}$ & $\begin{array}{l}\text { The grounds for the British opposition: (1) Korea was } \\
\text { a territory of Japan before 1945; (2) it remained } \\
\text { doubtful whether South Korea was a complete, single } \\
\text { sovereign state even after liberation. }\end{array}$ \\
\hline Jun. 18-20 & $\begin{array}{l}\text { well-disposed to South } \\
\text { Korean participation }\end{array}$ & & $\begin{array}{l}\text { This was expressed during John Foster Dulles’ visit to } \\
\text { South Korea. }\end{array}$ \\
\hline Jun. 25 & \multicolumn{3}{|c|}{ North Korean army crossed the 38th parallel. The Korean War broke out. } \\
\hline Jul. & $\begin{array}{l}\text { favorable appraisal for } \\
\text { South Korean } \\
\text { participation }\end{array}$ & & $\begin{array}{l}\text { The US State Department noted added stature to be } \\
\text { gained by the South Korean government from signing } \\
\text { the treaty. }\end{array}$ \\
\hline
\end{tabular}

Jan. 1951

Jan.-May 1951

Jan. 26

Mar. 11

Mar. 14

Mar. 21

Mar. 23

Apr. 16

Apr. 23

permitted South Korean participation opposed South Korean participation

Seoul was recaptured by the Allied forces.

permitted South Korean opposed South Korean participation participation

permitted South Korean participation

entertained reserved acceptance of South Korean participation
Dulles confirmed to South Korean Ambassador to the US Chang Myonthe US intention for a continued support for South Korean participation in the peace treaty and for efforts to dissuade Britain and Japan from opposing South Korean participation.

Britain drafted a note stating its concern for the Soviet Union to manipulate the situation of two Koreas.

US delegate John M. Allison expressed his wish to distribute the draft peace treaty to South Korea. British delegate Robert H. Scott conveyed British opposition on the grounds of Korea's different legal status.

The US government delivered the draft treaty to South Korea.

British Foreign Minister Herbert Morrison’s memo: “If the US government attach importance to South Korean participation, we need not insist on our view."

In a meeting between Yoshida Shigeru and Dulles, Dulles indicated that the US wished to build up the prestige of the South Korean government but that Japan's concerns over the Koreans in Japan (with many communists among them) and the issue of compensation rights for them should be addressed.

\footnotetext{
7 Except for the asterisked sections, Table 1 is based on Kang Seong Mo, “Great Britain's Postwar Insecurity and the Question of South Korean Participation in the Japanese Peace Treaty,” Seoul Journal of Korean Studies vol. 28-2, (2015): 153-179.
} 
Table 1 to be continued

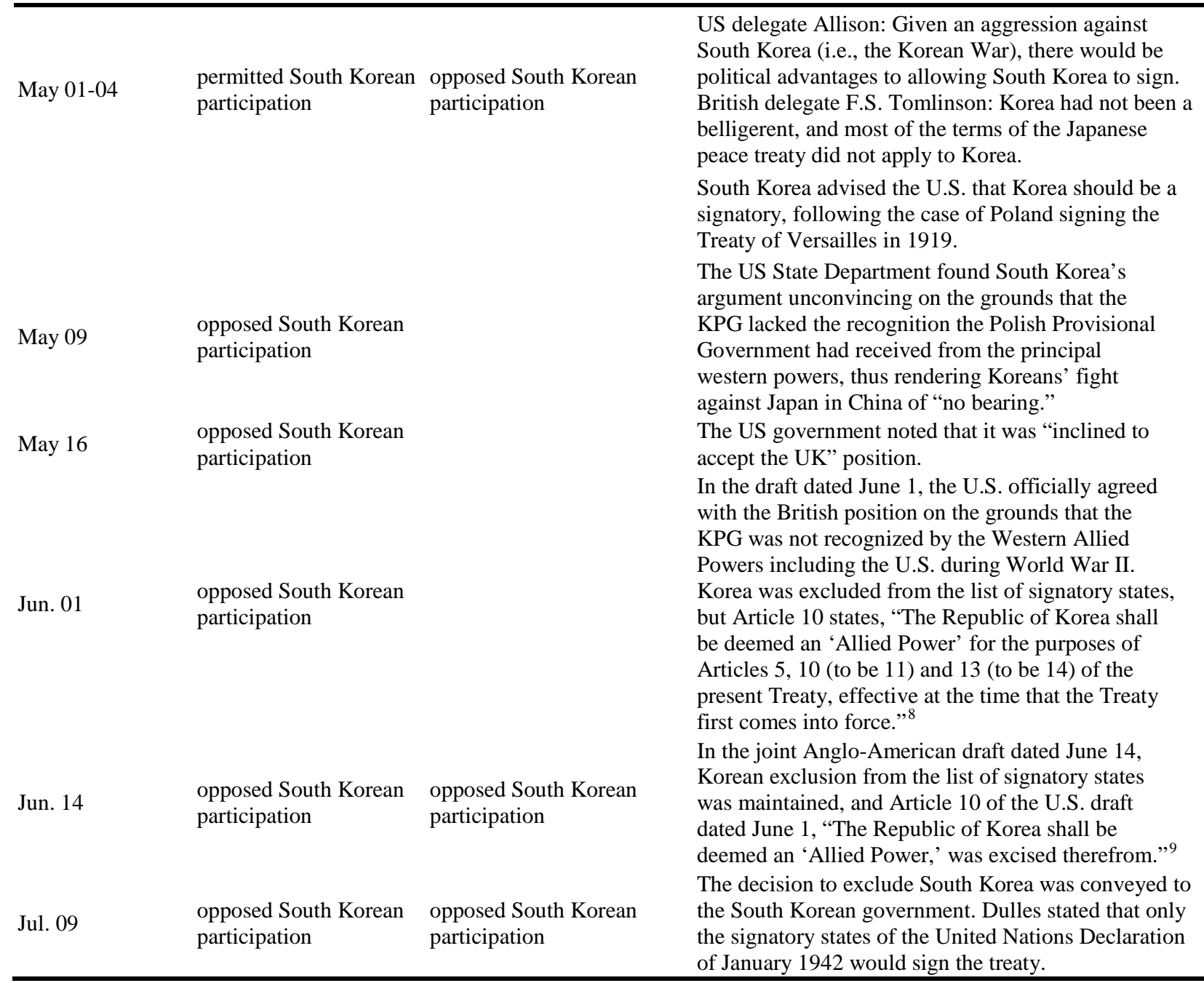

Note. Source: Kang Seong Mo, “Great Britain’s Postwar Insecurity and the Question of South Korean Participation in the Japanese Peace Treaty,” Seoul Journal of Korean Studies 28-2, (2015): 153-179.

The United States, as the representative of the Allied Powers, launched in October 1945 a task force in the State Department to conclude a peace treaty, but the treaty development process moved at a glacial pace for more than two years. This was also the case with the FEC, which was launched in July 1947 as the body responsible for the decisions of the Allied States on their rule over Japan. On August 29, 1947, the interim Legislative Assembly of South Korea conveyed to the US State Department its desire to participate in the anticipated peace conference with Japan. ${ }^{10}$ But in the words of US Secretary of State Dean Acheson, "The United States and British Governments, as well as others, attempted in 1947 to bring about a peace conference

\footnotetext{
8 “Japanese Peace Treaty: Working Draft and Commentary Prepared in the Department of State United States Department of State, Washington, 1 June, 1951,” Foreign relations of the United States (FRUS), 1951, Vol. VI, Part 1, (Washington DC: Government Printing Office, 1951), 1068.

9 “Revised United States-United Kingdom Draft of a Japanese Peace Treaty, London (?), 14 June, 1951,” Foreign relations of the United States (FRUS), 1951, Vol. VI, Part 1, (Washington DC: Government Printing Office, 1951), 1123.

10 "The Political Adviser in Korea (Jacobs) to the Secretary of State, Seoul, 29 August 1947," Foreign Relations of the United States (FRUS), 1947, Vol. VI (Washington DC: Government Printing Office, 1972), 511.
} 
and failed." ${ }^{11}$ For the better part of the year 1948, much attention was concentrated in the International Military Tribunal for the Far East (May 3, 1946-November 12, 1948).

The draft peace treaty with Japan that the U.S. disclosed in December 1949 included South Korea as a signatory. To this, the U.K. expressed its opposition for the first time in the same month. ${ }^{12}$ As described below, the U.K. did not agree with the United States on Korean participation due to its intention to establish diplomatic ties with the new communist People's Republic of China declared after the Chinese mainland fell to the communists in 1949. The rationale for the British opposition was that Korea was part of Japan's territory before 1945 and that it is difficult to view it as a complete, single state, presumably referring to the situation of the two divided Koreas. Nevertheless, the US intention to allow South Korean participation was maintained during Dulles's visit to Korea on June 18-20, 1950.

On June 25, 1950, the North Korean People's Army crossed the 38th parallel into the South and started a war. It was five days after Dulles visited Seoul. Despite, or perhaps because of, the extremely unfavorable war situation at the time, the U.S. State Department expressed its willingness to review South Korea's participation favorably again in July. As mentioned earlier, on January 4, 1951, the day the Chinese troops recaptured Seoul, Dulles sent a letter to State Secretary Acheson, advising that a peace treaty with Japan be swiftly concluded to orient Japan to the path of a peace-loving nation and that a security arrangement be urgently made in in Japan at the same time, with a view to guaranteeing Japan a measure of confidence in its relationship with the U.S against a possible Soviet-communist aggression. ${ }^{13}$ In the face of Chinese intervention in the Korean War, the US government took seriously the possibility of Soviet troops entering Japan through Hokkaido and hastened to set up a policy aimed at the dual goals of making Japan a liberal democracy and assuring Japan of sufficient security arrangements with the cooperation of the US military. It is well known that this US policy was embodied in the San Francisco Peace Treaty and the US-Japan Security Treaty that were signed in San Francisco in September of the same year. But it is worth noting that the impetus came from the Korean War, and especially from the Chinese intervention in that war.

Since January 1951, Dulles repeatedly expressed his intention to allow South Korean participation, citing two reasons. The first was that the Provisional Government of the Republic of Korea participated in the anti-Japanese war with China's Kuomintang government. The second was the need to raise the political stature of Korea, which was then fighting the communist forces. ${ }^{14}$ This argument in favor of South Korean

\footnotetext{
11 “The Secretary of State to Certain Diplomatic Offices, Washington, 27 December 1949,” Foreign Relations of the United States (FRUS), 1949, The Far East and Australasia, Vol. VII, Part 2, 931.

12 In response to the U.S. move to allow Korean participation in the treaty, the British side prepared in January 1950 a series of documents on the issue, one of which stated, "There is no doubt that Korea was a territory of Japan, and there is room for doubt as to whether or not it is a complete and single nation even today.” This was reportedly the opinion of Gerald C. Fitzmaurice, 2nd Legal Counsel. See Kim Minsoo 金民樹, “Tainichi kōwa jōyaku to Kankoku sanka mondai” 対日講和条約と韓国参加問題 [The Debate over Korean Participation in the Japanese Peace Treaty], Kokusai seiji 國際政治 131 (2002): 139. The appearance of these British documents coincided with the U.K.’s official recognition of the People’s Republic of China on 6 January 1950, which, according to Wolf (1983), was driven principally by the U.K.'s desire to "secure conditions favorable to British trade.” See Wolf, David C. “"To Secure a Convenience’: Britain Recognizes China-1950,” Journal of Contemporary History 18, no. 2 (1983): $299-326$.

13 See Footnote 5.

14 The United Nations recognized the Republic of Korea in 1948. The United States played a central role in this by successfully overcoming the opposition of the Soviet Union. At the time, it was none other than Dulles who was the representative of the United States. The United States was aware of the Cairo Declaration (November 27, 1943), which noted the "slave status" of Koreans under Japanese rule, and the fact that the Korean Provisional Government had declared war against Japan on December 10, 1941. See Kim Minsoo (2002), 138.
} 
participation was expressed five times after the Chinese intervention in January 1951, as shown in Table 1, until May 4. On the other hand, Britain opposed South Korean participation four times during the same period. ${ }^{15}$ On one occasion in April 16, British Foreign Minister Herbert Morrison stated in a Cabinet memorandum that “... if the US Government attach importance to this, we need not insist upon our view.”16 But this opinion was quickly overruled, and Britain continued in its opposition. ${ }^{17}$ The United States, which was consistently in favor of South Korean participation, leaned toward accepting the British opinion after May 9, and Korea was eventually unable to attend the San Francisco Peace Conference held in September.

\section{Reasons for the British Opposition: Maintaining Ties With the Chinese}

Britain opposed South Korean participation ostensibly because it would provoke the People's Republic of China (China) and the Soviet Union. In actuality, the priorities seem to have lain in protecting the British commercial and political stakes in China and Southeast Asia that had been maintained since the era of imperialism. In particular, the economic importance of China and Hong Kong took priority. ${ }^{18}$ In protecting these interests, the UK was faced with two major challenges: to establish amicable relations with China's new communist regime and to drive a wedge between China and the Soviet Union in order to prevent communist solidarity. ${ }^{19}$

At the end of World War II, the U.K. was facing a total economic ruin. Unlike that of the United States, the British economy was based on the economic structure of a colonial network. Economic relations with China, Hong Kong, and Malaya had significant implications for the world, especially the United Kingdom. China was a country with immense raw materials and trade potential. In 1949, British merchants and companies had substantial business interests in China for commercial trading. Hong Kong was one of the world's most important, thriving ports and markets. Shipbuilding and ship repairing there were of great import. ${ }^{20}$ It was politically and psychologically significant also as a base for anti-communism. Malaya was also of great importance to the Western economy as an area with such important resources as rubber, tin, and foods. The U.K. attempted to overcome its economic crisis by regaining the influence it had established in these areas before the war. At the same time, the U.K. tried to prevent the Chinese from aligning too closely with the Soviet Union. The combined forces of the Soviet Union's formidable military strength and China's massive

\footnotetext{
15 A study suggests that after the US draft was released in March 1951, the United Kingdom objected once more on April 11 to Article 18 regarding South Korea’s participation as a signatory state. See Tsukamoto Takashi 塚本孝, “Kankoku no tainichi hēwa jōyaku shomē mondai - Nitchō kōshō, sengo hoshō mondai ni kanren shite” 韓國の對日平和條約署名問題一日朝交涉, 戰後補償問題に關聯して [The Issue of Korea’s signing of the Peace Treaty with Japan: Japan-North Korea Negotiations, On Post-war Compensation], References レファレェンス 3 (1992).

16 Kang (2015), 160.

17 Kang (2015), 160.

18 For the economic concerns of the U.K. in Southeast and East Asia, see Kibata Yōichi (1986).

19 The following description on the reasons for British opposition to Korean participation is based on Kang (2015).

20 At the end of January 1951, there was a discussion between Dulles and the British Embassy in Tokyo about the size of shipbuilding facilities in Japan. In other words, the United States inquired about the size of the shipbuilding facilities identified thus far in order to hand over to Japan the shipbuilding facilities managed by the UK until then. According to a telegram (cryptograph) sent to the British Foreign Service Officer in Tokyo (C.P. Scott) to Sir A. Gascoigne of the British Foreign Office in London, the person responsible for the shipbuilding said that his shipbuilding adviser reported 700,000 tons of annual shipbuilding capacity. But it was reported that he believed it should be lowered to 400,000 tons. This was a preliminary arrangement by the UK to prevent Japan's shipbuilding industry from outperforming Hong Kong's after Japan's restoration to the status of a free, sovereign state by limiting Japan's capacity to not more than 400,000 tons per annum. Public Record Office, F.O. 371 closed until 1982, 92530. 1951, Far Eastern Department, Japan J 1022/36, From Tokyo to Foreign Office 38, Sir A. Gascoigne No. 111, 30th January 1951. The United Kingdom was also wary of the resurgence of Japan's textile industry.
} 
land forces would pose a major threat to the West. Communist rule of China was indeed "repugnant", but maintaining ties with China was unavoidable as a geopolitical exigency.

Dulles, who was negotiating the peace treaty with multilateral parties including the U.K., decided to forgo the US insistence on South Korean participation-presumably on the premise that British ties with China would help negate the Soviet predominance in the Far East. A Soviet invasion of Japan through Hokkaido was one of the most worrisome possibilities the United States contemplated, and apparently it was concluded that concurring with British policy would help prevent this. The United States thereupon officially changed its position from that espousing South Korean participation in the treaty as a signatory on the grounds of political advantages to that concurring with the British opposition to South Korean participation. In order to counter the British opposition, the South Korean government argued that South Korea should be a signatory just as Poland was in the 1919 Treaty of Versailles. On July 9, however, "Ambassador Dulles pointed out to the Korean Ambassador that the ROK Government would not be a signatory to the treaty, since only those nations in a state of war with Japan and which were signatories of the United Nations Declaration of January 1942 would sign the treaty."21

This reasoning was explained in more detail in the "Japanese Peace Treaty: Working Draft and Commentary Prepared in the Department of State" dated June 1, 1951, which states, "Article 10. The Republic of Korea shall be deemed an 'Allied Power' for the purposes of Articles 5, 10 (to be 11) and 13 (to be 14) of the present Treaty, effective at the time that the Treaty first comes into force. The reason for this proposal is that the United States now considers, in agreement with the British position, that Korea is not entitled to be a signatory to the treaty. The U.S. and other major powers deliberately refrained from recognizing the 'Provisional Government of Korea' as having any status whatsoever during World War II. The facts that that government declared war on Japan, and that Korean elements, mostly longtime resident in China, fought with the Chinese forces, do not, therefore, have any bearing on the question. The Korean Government has cited the fact that Poland was permitted to sign the Versailles Treaty. On examination, however, Korea's case for participation in the Japanese treaty does not gain much support from this example. The Polish National Committee set up in Paris in 1917 under Paderewski was 'recognized' and dealt with by all the principal western Allies."22

\section{Problems of Justification for Opposing Korean Participation: Inverse of the Spirit of International Law Under the U.N.}

When the United States notified the South Korean government of its final decision to exclude South Korea from the Japanese peace treaty, fierce battles were being raged along the 38th parallel. On March 14, 1951, when the UN forces pushed out the Chinese and restored Seoul, Commander MacArthur ordered the crossing of the 38th parallel to the north, and on June 25, the Soviet delegation to the U.N. proposed an armistice talk. But South Korean President Syngman Rhee refused and argued for “a unification of Korea.” On April 10, US President Truman dismissed Commander MacArthur, who had preferred a more aggressive strategy against the Chinese intervention, and on June 29, ordered Commander Matthew Bunker Ridgway, who had succeeded

\footnotetext{
21 "Memorandum of Conversation, by the Officer in Charge of Korean Affairs in the Office of Northeast Affairs (Emmons), 9 July 1951,” FRUS, 1951, Asia and the Pacific, Vol. VI, Part 1, 1183.

22 “Japanese Peace Treaty: Working Draft and Commentary Prepared in the Department of State, 1 June 1951,” FRUS, 1951, Asia and the Pacific, Vol. VI, Part 1, 1068-1069.
} 
MacArthur, to commence ceasefire negotiations. Amid the intense fighting between the UN forces and the communist forces that continued throughout the ceasefire negotiations, South Korea's hope to participate in the peace treaty with Japan was forsaken largely due to the British opposition, which in turn was driven by its policy not to antagonize Communist China.

Is Korea's exclusion justified? Is there a convincing argument for such a decision? To examine this, we need to compare the differing positions of the U.S. and the U.K.

On November 23, 1949, the US Acting Secretary of State sent a telegram to the US Embassy in Korea inquiring the US Ambassador's "views as to whether and to what extent provision [should] be made for Korean participation in [Japanese] treaty." ${ }^{23}$ On December 3, 1949, US Ambassador in Korea John J. Muccio suggested to the US State Secretary, "We are strongly of view ROK should be included in some capacity among nations participating in Japanese peace treaty. ... Accordingly, we do not anticipate Korean participation in negotiation of peace settlement would be serious source of embarrassment to other negotiating powers. Before extending any invitation to ROK to participate we could, if desired, privately inform ROK invitation contingent upon not presenting further reparations claim. In this connection we feel Korean eagerness to be signatory is such that ROK would agree to foregoing terms." ${ }^{24}$ This appears to have been the first instance of a US official speaking in favor of Korean participation. The US government maintained this view when Dulles negotiated with Britain between January 1951 and the first half of April. ${ }^{25}$ More specifically, it was mentioned that the Korean Provisional Government participated in the anti-Japanese war with China's Chiang Kai-shek Nationalist government. ${ }^{26}$ This is a view that officially acknowledges the anti-Japanese struggle of the KPG, which was established in Shanghai in April 1919.

On the other hand, when the U.S. State Department prepared a US draft treaty reflecting the recommendation from the U.S. Ambassador Muccio in Korea and presented it to the British government in December 1949, the British government opposed Korean participation in January 1950 on the following two grounds: (1) before 1945, Korea was a part of Japanese territory and (2) it was difficult to view it as a complete, single state even after liberation. On April 23, 1951, Japanese Prime Minister Yoshida Shigeru offered a similar opinion in the "Korea and Peace Treaty" presented to Dulles who visited Tokyo at the time. Yoshida Shigeru added that if South Korea were to become a signatory, property rights and reparations for nearly one million Koreans residing in Japan would be a problem. He also mentioned that most of those Koreans were communists. $^{27}$

\footnotetext{
23 “The Acting Secretary of State to the Embassy in Korea, 23 November 1949,” FRUS, 1949, The Far East and Australasia, Vol. VII, Part 2, 904.

24 "The Ambassador in Korea (Muccio) to the Secretary of State, 3 December1949,” FRUS, 1949, The Far East and Australasia, Vol. VII, Part 2.

25 "Ambassador Dulles said that it has always been the U.S. position that Korea should participate, and that he has held as full discussion with the Korean Government regarding the treaty as with most FEC countries. He explained that with the initial discussions with our Allies completed, he had come to Japan to obtain the views of the Japanese Government on the United States seven-point statement of principles, following which he planned to talk again with representatives of the FEC nations, Indonesia, Korea and Ceylon. He said that the procedure of bilateral discussions had been adopted largely in order to deprive certain nations of opportunity to maintain that the North Korean and Chinese Communist regimes, rather than the Republic of Korea and the Chinese National Government, should represent Korea and China in the negotiations, and that the United States would continue to support the right of the ROK to participate in the Japanese peace settlement." "Memorandum of Conversation, by Mr. Robert A. Fearey of the Office of Northeast Asian Affairs, 26 January 1951,” FRUS, 1951, Asia and the Pacific, Vol. VI, Part 1 (Washington DC: Government Printing Office, 1977), 817.

${ }^{26}$ Kim Minsoo (2002).

${ }^{27}$ Kang (2015), 160.
} 
The US view emphasized the fact that Korea's Chongqing Provisional Government established the Korean Liberation Army and participated in the anti-Japanese front with the support and cooperation of the Chiang Kai-shek' KMT government forces. It was remembered that the Liberation Army established operations with US or British troops in western China. The British would also have remembered this but turned away for other reasons. As noted above, finding it critical to maintain post-war economic relations with China, the British disregarded the facts. They were concerned that Korean participation would provoke China and the Soviet Union, which might cause friction with these two countries.

It is true that the Korean Provisional Government did not receive official recognition from the League of Nations before August 1945. However, the situation in East Asia caused by Japan's Mukden (Manchurian) Incident in 1931 deprived the League of Nations of any opportunity to do so. At the time of the Incident, the League of Nations had just secured a legal basis for dealing with international disputes and sent the Lytton Commission to the area in dispute to investigate the incident. In 1932, the Commission found Japan's action as aggression violating international law and "recommended" a restoration to the state prior to the Incident. But the Japanese Empire rejected the Commission's findings and withdrew from the League of Nations. Japan thereupon moved itself into the path of militarism and soon launched the Second Sino-Japanese War and then the Pacific War. Under these circumstances, it was hardly feasible for the Korean Provisional Government to be formally recognized by the League of Nations, which barely started reviewing wrongful deeds of aggressor states such as the Japanese Empire. In fact, however, a remarkable achievement was made when the 1935 Report on the Law of Treaties identified the 1905 "Protection Treaty" as a treaty without any legal effect due to its patently coercive nature. It would be fair to say that if such a major work of the League of Nations concluded that the treaty by which the Japanese Empire, for all practical purposes, turned Korea into its "colony" was indeed without any legal effect from its inception (void ab initio), then it follows that the League of Nations found the consequent Japanese occupation of Korea ipso facto illegal. Such a conclusion was tantamount to a tacit acknowledgement of the Korean Provisional Government that was fighting against Japan's "illegal" occupation of Korea. Around that time, Germany and Italy, which followed the path of fascism after Japan, withdrew from the League of Nations one after another, and the world reentered the phase of an impending world war. In this historical context, the significance of the 1935 Report on the Law of Treaties cannot be ignored. ${ }^{28}$ This is especially the case if the report was inherited, as it was, by the newly formed United Nations that assumed the mantle of the League of Nations after World War II.

\footnotetext{
28 The Report on the Law of Treaties, a result of the League of Nations' codification of international law, based its findings about the 1905 Protectorate Treaty on Francis Rey’s study on the Treaty titled "La situation internationale de la Corée”, Revue Générale de Droit International Public, Tome XIII (Paris: 1906). Francis Rey was a member of the delegation of France at the 1919 Paris Peace Conference and later served as the Secretary General of the International Committee of the Donau River. Yi Tae-jin 李泰鎭, Kkeutnaji anheun yeoksa - sikminjibae cheongsan-eul wihan yeoksainsik 끝나지않은 歷史-植民支配清算을爲한歷史 認識[Unfinished History: Historical Perspective on Settling Issues with Colonial Rule], (Seoul: Taehaksa, 2017), 257-258. James Garner, a reporter of the Report on the Law of Treaties, was a professor at the University of Illinois in the United States, but he was fluent in French and spent much of his time conducting academic activities in France. Thus, it is highly likely that James Garner was in contact with Francis Rey. When a delegation from the Korean Provisional Government submitted its appeal to the 1919 Paris Peace Conference, the Secretary-General sent a reply at the end of the Conference stating that this was a matter that should be addressed by the League of Nations soon to be established. If so, the determination of the 1905 Protectorate Treaty as void ab initio in the Report on the Law of Treaties can be construed as the League's public reply to the KPG's appeal. Yi (2017). Yi Tae-Jin, "San Francisco Peace Treaty with Japan and the Problems with the 'Colony' Korea: Criticizing the Unjust Condoning of the Japanese Colonization of Korea Despite the Judgements of Illegality of the 1905 'Protectorate Treaty' by the League of Nations and the United Nations," Proceedings of the international conference, "Beyond the San Francisco System: Seeking a Peace Regime in East Asia,” October 28, 2016.
} 
The League of Nations was credited with promoting international law to the status of public law, but its weakness was that it had no sanctions regime against aggressor states. To remedy this defect, the formation process of the United Nations began in 1942, and the new organization officially commenced in December 1946. The following year the League of Nations voluntarily dissolved. The League's codification of international law had been led by Manly Hudson, and Hudson once again became the driving force behind the formation of the International Law Committee under the UN, which accepted the results of the League's codification project in toto, as mentioned above. In 1963, the UN International Law Committee supplemented the Report on Treaty Law of the League of Nations and submitted this supplemented report to the UN General Assembly, which adopted it in Resolution 1902. In this new report, Nazi Germany's coercive treaty for the partition of Czechoslovakia was added to the list of the above-mentioned three treaties that the 1935 Report viewed as without legal effect ab initio on the grounds that they were extracted under duress.

The United States is the nation that led the creation of the League of Nations and the United Nations. Professor Manly Hudson, who spearheaded the codification of international law as carried out under the auspices of the League of Nations, described this work as "the realization of the Grotian spirit in the 20th century." Premised on the requirement of full disclosure of all treaties to be signed, this codification effort was pursued in order to bring an end to the unlawful and illicit practice of using secret agreements between great powers, which was spurred on by fierce colonial competition prevalent at the turn of the century. International law that had existed until then as mere academic theories became recognized as belonging to the sphere of public law. "Grotian spirit” thus represented was concerned with the pursuit of international justice, rather than the maximization of the interests of great powers. From this perspective, it was perfectly reasonable for the US government to argue that Korea should participate as a signatory state in the San Francisco Peace Treaty. And it was a grave error to change its position and eventually accept Britain's argument against Korean participation, due to concerns arising from a possible Soviet aggression against Japan following the Chinese intervention in the Korean War. One cannot but wonder if the influence Britain and Japan exerted to bring about this change was not a throwback to the imperialistic era, where imperial self-interest was placed above all else. Regarding the British involvement in the US-led peace settlement with Japan, there is a noteworthy comment as follows: "The British government, still regarding itself as a great imperial power in East Asia and the Pacific, endeavored to intervene in the US-led peace treaty from the position equal to that of the U.S. as much as possible.”29

\section{Conclusion: Modifiability of the San Francisco Peace Treaty}

The Japanese Empire initiated four major wars during the span of 60 years from the end of the 19th century to the first half of the 20th century: the First Sino-Japanese War in 1894, the Russo-Japanese War in 1904, the Second Sino-Japanese War in 1937, and the Pacific War in 1941. Japan has attempted to explain away all these wars as unavoidably caused by unexpected upheavals in international affairs. However, initial plans were laid well before the actual launching of these wars of aggression, which were in fact executed methodically by the Chōshū clique, after they overthrew the shogunate and established the Meiji government in accordance with the teachings of their deceased master Yoshida Shōin, who was executed in 1859 for his failed attempt to overthrow the shogunate. A master plan of foreign expansion propagated by Yoshida Shōin, as delineated in his 1854 book titled Record From Prison (Yūshūroku幽囚錄), eerily matches the actual

${ }^{29}$ Kibata Yōichi (1986), 185. 
progression of wars the Chōshū clique treaded ever since the Meiji Reform. Suddenly faced with encroaching steamships, Yoshida Shōin writes, Japan, an island country, is made vulnerable and must act quickly before it falls victim to Western conquest. His solution: Absorb advanced technologies of Western powers fast and then conquer neighboring countries first before the Western powers do. He even mapped out the sequence of such military conquests: Hokkaido, Kamchatka, Ryukyu islands, Taiwan, Korea, Manchuria, Mongolia, and China. His next goal was continued expansion into Australia and California to make the Pacific the sea of Japan. ${ }^{30}$ In hindsight, it would be more apt to describe these wars, all of which were faithfully carried out one after another as per Yoshida's master plan, as "premeditated warfare."

If the San Francisco Peace Treaty could be called a treaty for a true peace, Japan should have been held accountable for all these wars. While the Japan Peace Treaty of 1951 is said to have been concerned only with the Second Sino-Japanese War and the Pacific War, even that is not quite right because one party to the former, China, was absent. Korea arguably suffered the greatest damage from these four wars, but it was not even invited to the peace conference because it was "annexed" to Japan in 1910 and became a part of its territory. The Russo-Japanese War of 1904 was a war that Japan launched to make Korea a protectorate. On the basis of the Japan's victory over Russia, a "protection treaty” was coerced upon Korea, and based on this treaty, the coercive annexation of Korea was carried out in 1910. Koreans' active pursuit of the recovery of their national sovereignty attracted great attention at the Second Hague Peace Conference in 1907 and the Paris Peace Conference in 1919. There also exists the historic 1935 Report on the Law of Treaties, in which the 1905 Protectorate Treaty was designated as one of the three treaties that were void from their inception. Nevertheless, those responsible for the San Francisco Peace Conference ignored all this and resorted to the coerced annexation and the consequent occupation of Korea, i.e., the argument "that Korea was a part of Japanese territory," as the grounds for the exclusion of Korea from the peace treaty. A peace conference that should have penalized acts of aggression ended up justifying acts of aggression. The drafters of the San Francisco Peace Treaty, unaware of the reasons why the Second Sino-Japanese War and the Pacific War occurred, ended up giving preferential treatment to the aggressor.

The San Francisco Peace Treaty was a treaty devised to save Japan from Soviet-communist threat within the context of the Cold War system, rather than a treaty intended to bring its war crimes to justice. At the opening of the conference, President Truman of the United States, who hosted the Peace Conference, stressed, "The treaty recognizes the principle that Japan should make reparations to the countries which suffered from its aggression. But it does not saddle the Japanese people with a hopeless burden of reparations which would crush their economy in the years to come.” The San Francisco Peace Treaty aimed to make Japan a sovereign state capable of entering into treaties needed for defense against the threat of communist aggression then looming large in Northeast Asia. In other words, it was a prerequisite step toward the conclusion of the US-Japan Security Treaty that immediately followed it. Even if this strategic judgment of the U.S. and the U.K. was unavoidable in the face of the formidable communist menace in Northeast Asia, "the principle that Japan should make reparations to the countries which suffered from its aggression" should have been honored properly. Was Korea not the country that suffered the most by the aggression of the Japanese Empire? Was

${ }^{30}$ See Yi (2017), 145, and Yi Tae-Jin 李泰鎭, “Yoshida shōin to Tokutomi Sohō—kindainihon ni yoru Kankoku shinryaku no shisō-teki kitei” 吉田松陰と德富蘇峰-近代日本にょる韓國侵略の思想的基底 [Yoshida Shoin and Tokutomi Soho-Modern Japan's Ideological Base in the Colonization of Korea], Tsuru Bunka Daigaku Kenkyu Kiyo 都留文科大學研究 紀要 80 (2007): 175-202. 
South Korea not the country battling against the Communists at the forefront? If all these problems remain unrectified, this treaty will live in infamy in the history of treaties.

The San Francisco Peace Treaty, as a multilateral treaty, also had many problems in form. Unlike Korea, which was not invited on the grounds that it was part of its territory as a Japanese colony, Pakistan, India, Ceylon, Indonesia, Vietnam, Laos, Cambodia, and others became treaty signatories on the grounds that those countries were former colonies of the Allied Powers (U.K., Netherlands, and France). It was "a far cry from fair or rational decision making." ${ }^{31}$ It was an unfair dealing brought about through the influence of the U.K., which once possessed the largest number of colonies in history. It is also important to remember that the Italy voiced dissatisfaction with the preferential treatment Japan received in the San Francisco Peace Treaty, terms of which was far more lenient than those of the Treaty of Peace with Italy signed on February 10, 1947. This led to a public outcry in Italy for demanding a revision of the Treaty of Peace with Italy. ${ }^{32}$

The extent of Britain's involvement in the San Francisco Peace Treaty was excessive considering Britain's actual contribution to the Pacific War. This has already been criticized as a result of "having failed to break with its self-identification as a great imperial power in the East Asia-Pacific region”, but the error caused by the exercise of the undue influence should be corrected. Above all, if the British argument provided an opportunity for Prime Minister Shigeru Yoshida to activate his imperialistic mentality, that must be considered significant.

In conclusion, the San Francisco Peace Treaty produced a result in which the Cold War logic and the imperial mindset intermingle, and this unreasonableness still acts as one of the major causes of geopolitical instability in Northeast Asia. For the true peace of East Asia, new efforts will have to be made in the name of the United Nations and in the "Grotian spirit of international law in the 21st century" (22 September 2019).

\section{References}

Dower, J. (1991). Empire and aftermath: Yoshida Shigeru and the Japanese experience, 1878-1954 吉田茂とその時代. (G.

Okubo 大涳愿二, Trans.). Tokyo: Chuokoron-Shinsha 中央公論新社. (Original work published 1979)

Dudden, A. (2008). Troubled apologies among Japan, Korea, and the United States. New York: Columbia University Press.

Fukunaga, F. 福永文夫. (2014). Nihon senryōshi, 1945-1952: Tokyo-, Washington, Okinawa 日本占領史 1945-1952, 東京·ワ

シントン・沖繩 [A History of the Occupation of Japan, 1945-1952: Tokyo, Washington, Okinawa]. Tokyo: Chuokoron-Shinsha 中央公論新社.

Hara, K. 原貴美惠. (2012). Sanfuranshisuko hēwa jōyaku no mōten サンフランシスコ平和条約の盲点 [Blind Spots of the San Francisco Peace Treaty]. Hiroshima: Keisui-sha 溪水社.

Jeong, B. 鄭秉峻. (2010). Dokdo 1947 독도 1947 [Liancourt Rocks 1947]. Seoul: Dolbegae 돌베개.

\footnotetext{
31 Jeong Byeongjun 鄭秉峻, Saenpeulansiseuko pyeonghwa joyag-ui hanbando gwanlyeon johang-gwa hangug jeongbu-ui daeeung 샌프란시스코平和條約의韓半島關聯條項과韓國政府의對應 [Articles on the Korean Peninsula in the San Francisco Peace Treaty and Responses from the Korean Government thereto] (Seoul: Center for Diplomatic History Studies of the Korea National Diplomatic Academy, 2018), 122.

${ }^{32}$ Kim (2002), 137. A study suggests that the handling of territorial issues in the Peace Treaty with Japan was not as sufficiently detailed as that in the Peace Treaty with Italy. See Kang Pyung-Keun 강병근, "Pyeonghwa joyag nae yeongto johang-e gwanhan yeongu—daeil pyeonghwa joyag-gwa dae itaeli pyeonghwa joyag-eul jungsim-euro” 平和條約內領土條項에關한研究一對日 平和條約과對이태리平和條約을中心으로-[A Comparative Study on the Provisions on Territories in the Peace Treaty with Italy in 1947 and the Peace Treaty with Japan in 1951], Gukje Beophakhoe Nonchong 國際法學會論叢 63(4) (2018): 217-245.
} 
Jeong, B. 鄭秉峻. (2019). Saenpeuransiseuko pyeonghwa joyag ui hanbando gwanlyeon johang gwa hangug jeongbu ui daeeung 샌프란시스코 平和條約의 韓半島 關聯條項과 韓國政府의 對應 [Articles regarding the Korean Peninsula in the San Francisco Peace Treaty and Responses from the Korean Government thereto]. Seoul: Center for Diplomatic History Studies of the Korea National Diplomatic Academy 국립외교원 외교사연구센터.

Miura, Y. 三浦陽一. (1996). Yoshida Shigeru to Sanfuranshisuko kōwa 吉田茂とサンフランシスコ講和 [Yoshida Shigeru and the San Francisco Peace Talks]. Tokyo: Otsuki Shoten 大月書店.

Nam, G. 남기정. (2016). Giji gukga ui tansaeng: Ilbon i chireun Hanguk jeonjaeng 기지국가의 탄생-일본이 치른 한국전쟁 [The birth of a base state: the Korean War that Japan undertook]. Seoul: Seoul National University Publishing Culture Center 서울대학교출판문화원.

Seo, S. 徐相文. (2004). Mo Taekdong gwa 6.25 jeonjaeng: pabyeong gyeoljeong gwajeong gwa gaeip donggi 毛澤東과 6.25戰 爭: 派兵決定過程㣉介入動機 [Mao Zedong and the Korean War: his motives and decision-making process in sending troops to the war]. Seoul: Institute for Military History, MND 國防部軍事編纂研究所.

Watanabe, A. 渡辺昭夫 \& Miyazato, S. 宮里政玄. (1986). Sanfuranshisuko kōwa サンフランシスコ講和 [San Francisco Peace Talks]. Tokyo: University of Tokyo Press 東京大學出版會.

Yi, T. 李泰鎭. (2017). Kkeutnaji anheun yeoksa: sikminjibae cheongsam eul wihan yeoksa insik 끝나지 않은 歷史-植民支配 淸算을 爲한 歷史認識 [Unfinished history: historical perspective on settling issues with colonial rule]. Seoul: Taehaksa 태학사. 